\title{
Low Doses of Bovine Somatotropin During the Transition Period and Early Lactation Improves Milk Yield, Efficiency of Production, and Other Physiological Responses of Holstein Cows*
}

\author{
M. S. Gulay,† M. J. Hayen, M. Liboni, T. I. Belloso, C. J. Wilcox, and H. H. Head \\ University of Florida, Department of Animal Sciences, \\ Gainesville 32611-0910
}

\begin{abstract}
The objectives of this experiment were to determine whether low doses of bovine somatotropin (bST) during the transition period and early lactation period improved dry matter intake (DMI), body weight (BW), or body condition score (BCS); provoked positive changes in concentrations of somatotropin, insulin, insulin-like growth factor-I (IGF-I), glucose, nonesterified fatty acids, and Ca; or improved milk yield (MY) response without obvious adverse effects on health status. Eighty-four multiparous Holstein cows completed treatments arranged in a $2 \times 3 \times 2$ factorial design that included prepartum and postpartum bST, dry period (30 d dry, $30 \mathrm{~d}$ dry + estradiol cypionate, and $60 \mathrm{~d}$ dry), and prepartum anionic or cationic diets. Biweekly injections of bST began at $21 \pm 3 \mathrm{~d}$ before expected calving date through $42 \pm 2 \mathrm{~d}$ postpartum (control $=0$ vs. $\mathrm{bST}=10.2 \mathrm{mg}$ of $\mathrm{bST} / \mathrm{d}$; POSILAC). At $56 \pm 2 \mathrm{~d}$ in milk, all cows were injected with a full dose of bST (500 mg of bST/14 d; POSILAC). During the prepartum period and during the first $28 \mathrm{~d}$ postpartum, no differences in mean BW, BCS, or DMI were detected between the bST treatment group and the control group. During the first $10 \mathrm{wk}$ of lactation, cows in the bST treatment group had greater mean MY and 3.5\% fat-corrected milk yield and lower SCC than did cows in the control group. When cows received a full dose of bST, an increase in milk production through wk 21 was maintained better by cows in the bST group. Mean concentrations of somatotropin, IGF-I, and insulin differed during the overall prepartum period ( $\mathrm{d}-21$ to -1$)$. During the postpartum period ( $\mathrm{d} 1$ to 28 ), cows in the bST group had greater mean concentrations of somatotropin and IGF-I in plasma. Concentrations of $\mathrm{Ca}$ around calving
\end{abstract}

Received July 18, 2003.

Accepted October 24, 2003.

Corresponding Author: H. H. Head; e-mail: head@animal.ufl.edu.

*Florida Agricultural Experiment Station Journal Series No. R09493.

$\dagger$ Current address: Department of Physiology, Faculty of Veterinary Medicine, Akdeniz University, Burdur, Turkey. did not differ because of bST treatment. Results suggest that changes in concentrations of blood measures provoked by injections of bST during the transition period and early lactation period resulted in improved metabolic status and production of the cows without apparent positive or negative effects on calving or health.

(Key words: somatotropin, milk yield, dry matter intake, transition period)

Abbreviation key: CUD = close-up dry, ECP = estradiol cypionate, $\mathbf{M E}=$ mature equivalent; $\mathbf{M Y}=$ milk yield, $\mathbf{N E B}$ = negative energy balance.

\section{INTRODUCTION}

Increased milk yield (MY) occurs when cows are injected with bST (POSILAC; $500 \mathrm{mg} / 14 \mathrm{~d}$ ) beginning about 60 d postpartum (Chalupa and Galligan, 1989; Bauman, 1992, 1999). It has been speculated that treatment with bST during the transition period would increase MY and act as a prophylactic agent; it has also been speculated that the resulting physiological changes would decrease incidences of acute health problems such as ketosis, fatty liver, wasting disease, or susceptibility to other diseases. However, Bines and Hart (1982) suggested that injections of bST during early lactation may result in lower than expected MY responses because of delayed increase in DMI. Although Putnam et al. (1999) reported a significant positive effect of prepartum bST on MY during early lactation, other studies failed to detect an increase in MY when cows were injected prepartum with either high or reduced amounts of bST (Bachman et al., 1992; Simmons et al., 1994; Eppard et al., 1996).

As was reported for bST injection prepartum, bST injection during the early postpartum period often yielded inconsistent results. When cows were injected with $500 \mathrm{mg}$ of bST/14 d from 10 to $150 \mathrm{DIM}$, MY during the first $60 \mathrm{~d}$ did not differ between treatments (Moallem et al., 1997). Morever, the BCS of injected cows decreased significantly more than that of uninjected cows, and postpartum conception rate also was affected adversely (Moallem et al., 1997). When the 
same dose of bST was injected biweekly from 10 through 150 DIM, MY increased, but there was an extensive period of negative energy balance (NEB) and a decrease in BW and BCS despite an increase in DMI after the bST treatment was initiated (Moallem et al., 2000). On the other hand, Stanisiewski et al. (1992) injected 5 or $14 \mathrm{mg}$ of bST/d from 14 through 60 DIM and showed that cows that received these injections produced more FCM than controls, but yields did not differ between the two bST-treated groups. However, those cows injected with the lower dose ( $5 \mathrm{mg} / \mathrm{d}$ ) had higher conception and pregnancy rates than the other experimental cows.

In previous studies, bST injections (10.2 mg of bST/ d) during both prepartum and postpartum periods resulted in greater daily MY and 3.5\% FCM yields (Gulay et al., 2000, 2003b). Apparently, injecting bST during both prepartum and postpartum periods caused metabolic changes that were beneficial to cows during the lactating phase. For example, prepartum and postpartum injections of bST caused increased concentrations of somatotropin, IGF-I, and triiodothyronine in plasma and positive effects on DMI, BCS, BW, and MY (Gulay et al., 2000, 2001, 2003b). However, the MY response of cows to a full dose of bST beyond 60 DIM was not determined because bST injections were not continued after the last low postpartum dose had been injected.

We speculated that injecting low doses of bST prepartum and postpartum would increase MY and that cows would show greater milk yield response, which would be sustained or increased when a full dose of bST began at $56 \pm 2$ DIM. Therefore, major objectives of the present study were to evaluate effects of low doses of bST prepartum and postpartum on DMI, BCS, BW, somatotropin, insulin, IGF-I, and metabolite concentrations prepartum and postpartum and to evaluate the overall MY during early lactation and MY response to a full dose of bST in cows previously injected with low doses of bST during the transition and early lactation periods.

\section{MATERIALS AND METHODS}

\section{Experimental Design}

Eighty-seven multiparous Holstein cows were assigned randomly to a $2 \times 3 \times 2$ factorial arrangement of treatments approximately 8 to 9 wk before expected calving dates. The experimental protocol was approved by the Institutional Animal Care and Use Committee of the University of Florida. Parity of cows ranged from 1 to 5 , and BW and BCS ranged from 575 to $870 \mathrm{~kg}$ and from 3.00 to 4.75 , respectively. Cows in the bST treatment group $(\mathrm{n}=42)$ were injected biweekly $(0.4$ $\mathrm{mL}$ bST; POSILAC) to provide approximately $10.2 \mathrm{mg}$ $\mathrm{bST} / \mathrm{d}$. Injections began $21 \pm 3 \mathrm{~d}$ before expected calving dates and were continued up to $42 \pm 2 \mathrm{~d}$ postpartum; cows in the control group $(n=42)$ did not receive injections during the same time period. At $56 \pm 2 \mathrm{~d}$, all cows on the experiment received the full dose of bST biweekly (500 mg/14 d; POSILAC). Cows in both the control and bST treatment groups were assigned to three different dry period treatments and were fed either anionic or cationic diets prepartum as described in Gulay et al. (2003a). Briefly, cows were assigned to a 30-d dry period, a 30-d dry period + estradiol cypionate (ECP), or a 60-d dry period. Cows in the 30-d dry period $(n=28)$ and in the 30-d dry period + ECP $(n=29)$ differed in that cows in the latter group were provided an expected 30-d dry period and received the cottonseed oil excipient and $15 \mathrm{mg}$ of ECP (Pharmacia \& Upjohn, Kalamazoo, MI). At final milk removal, single injections of excipient or ECP $(7.5 \mathrm{~mL})$ were administered i.m. into the upper caudal face of the hind leg using a 20-gauge needle. Cows in the 60-d dry period group $(n=27)$ received no ECP or excipient injection. One-half of the cows in the control and bST groups were fed either an anionic or cationic diet during the 3 wk before expected calving. Three cows were removed from the experiment because of paratuberculosis, severe mastitis, and displacement of abomasum, respectively. Those cows were in the following, respective treatment groups: treated with bST, 60-d dry period, cationic diet; control group, 30-d dry period, anionic diet; control group, 30-d dry period + ECP, and anionic diet. A total of 84 cows completed the experiment $(150 \mathrm{~d})$, and their data were included in statistical analyses.

\section{Feeding Program}

All cows were housed and managed in a free-stall barn beginning $30 \mathrm{~d}$ before expected calving. They were trained to use electronic feed gates (American Calan, Inc., Northwood, NH) and were fed once daily (1000 to $1200 \mathrm{~h}$ ) with daily feed adjustments made to allow for 5 to10\% daily orts. During the training period, cows were fed a cationic close-up dry (CUD) diet ( $100 \mathrm{~g}$ of DM) formulated for the average weight of the cows. Starting 3 wk before expected calving date, cows

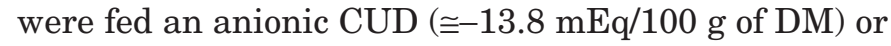
they continued on the same cationic CUD (Table 1). After parturition, all cows were fed a TMR based on corn silage, whole cottonseeds, and grain concentrate. This ration met the requirements (NRC, 1989) of highproducing lactating cows (Table 1).

\section{BCS and BW}

Body condition scores $(1=$ thin to $5=$ fat; scored at 0.25-pt intervals; Ferguson et al., 1994) and BW of cows were recorded at 60 and $30 \mathrm{~d}$ before expected calving 
Table 1. Dry matter concentrations (kg) and chemical composition of anionic and cationic close-up dry (CUD) and lactation TMR fed to Holstein cows. ${ }^{1}$

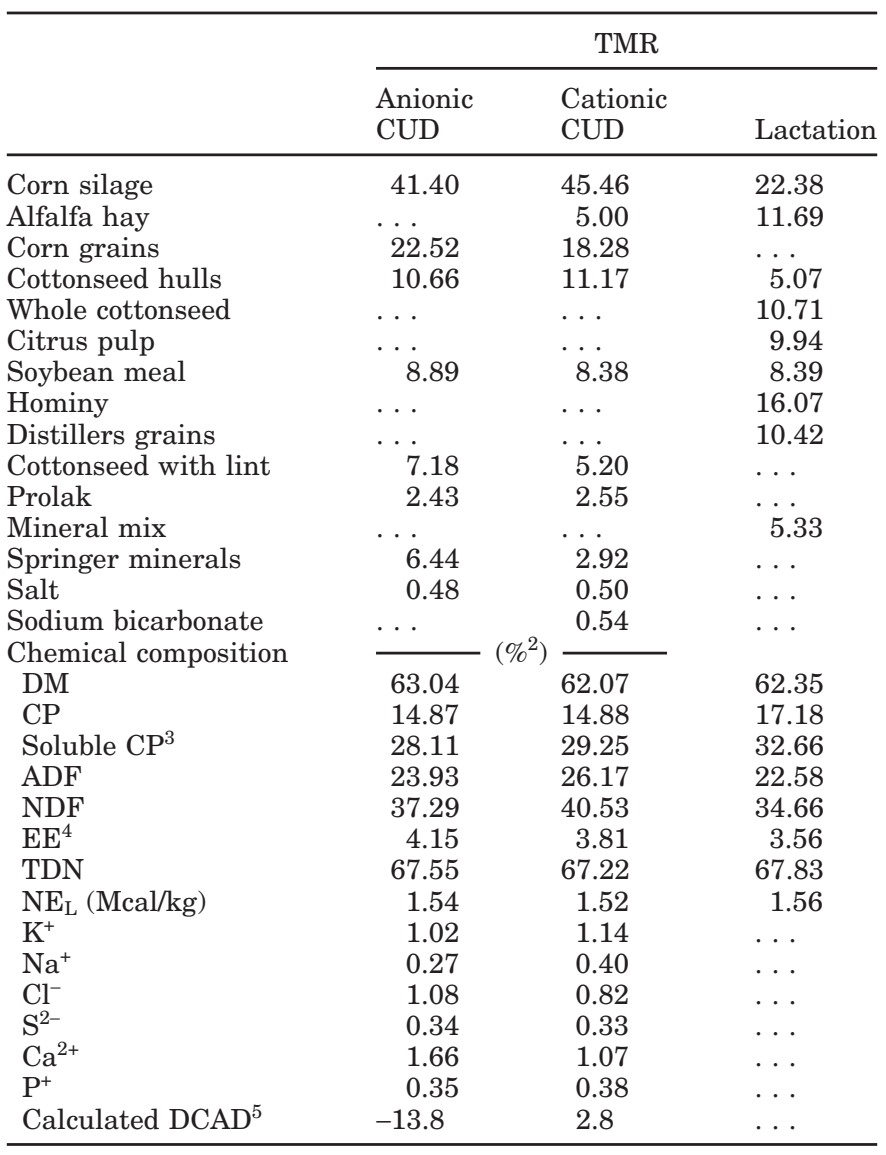

${ }^{1}$ From NE DHIA Forage Laboratory (Ithaca, NY) analyses of components.

${ }^{2} \mathrm{DM}$ basis.

${ }^{3}$ Percentage of the CP.

${ }^{4} \mathrm{EE}=$ ether extract.

${ }^{5}$ Measured in meq/100g of DM.

and then weekly on the same day each week prior to a.m. feeding or milking $(0600$ to $0830 \mathrm{~h})$ through $28 \mathrm{~d}$ postpartum. Thereafter, BCS and BW were determined biweekly up to $\sim 100 \mathrm{~d}$ postpartum.

\section{Milk Samples}

Milk yield was recorded at each of the 3 daily milking shifts from 3 to 150 DIM, and milk samples were collected on the same day each week during 3 consecutive milking shifts $(0830,1500$, and $0130 \mathrm{~h})$ through $10 \mathrm{wk}$ of lactation. Milk samples $(50 \mathrm{~mL})$ were analyzed for contents of fat, protein, and SCC at Southeast Milk Laboratory, Inc. (Belleview, FL).

\section{Blood Collection, Handling, and Storage}

Blood samples from 80 cows (41 on the control treatment and 39 assigned to bST treatment) were collected from the coccygeal vein thrice weekly before the a.m. feeding or milking (0600 to $0830 \mathrm{~h}$ ) using 20-gauge Vacutainer needles $(2.54 \mathrm{~cm})$ and $10-\times 100-\mathrm{mm}$ tubes containing sodium heparin (Becton-Dickinson, Fairlawn, NJ). They were placed on ice immediately after collection and centrifuged within $2 \mathrm{~h}$ at $3000 \mathrm{RPM}$ for 30 min at $5^{\circ} \mathrm{C}$ (Jouan GR 412 centrifuge; Winchester, VA). For serum collection, Vacutainer brand tubes containing no anticoagulant were used $(10-\times 100-\mathrm{mm}$ blood collection tubes; Becton-Dickinson). These samples were allowed to clot at room temperature for $\sim 1 \mathrm{~h}$, then placed on ice and processed within $2 \mathrm{~h}$. Plasma and serum were harvested and stored in capped polypropylene tubes at $-20^{\circ} \mathrm{C}$ until analyzed.

Double antibody radioimmunoassay procedures were used to determine concentrations of somatotropin (Garcia, 1998), IGF-I (Abribat et al., 1990), and insulin (Malven et al., 1987) in plasma. An enzymatic colorometric procedure (NEFA C; Wako Pure Chemical Industries, Osaka, Japan) was used for quantitative determination of NEFA in plasma as described by Johnson and Peters (1993). Glucose was analyzed using glucose oxidase procedure (Kit 510; Sigma Diagnostics, St. Louis, MO) as described by Raabo and Terkildsen (1960). Glucose and NEFA assays were carried out in 96-well microtiter plates. Serum samples for determination of $\mathrm{Ca}$, prepared according Miles et al. (2001), were analyzed using a flame atomic absorption spectrophotometer (PerkinElmer Model 5000).

\section{Statistical Analyses}

Data for BW, BCS, DMI, MY, somatotropin, insulin, IGF-I, glucose, NEFA, and Ca were analyzed by PROC GLM least squares ANOVA (SAS, 1991). The PROC MIXED procedure of SAS was used to estimate individual daily and/or weekly least squares means for specific variables and treatments (Littell et al., 2000).

Mathematical models included the main effects of treatment (TRT); dry period treatment (DRY); prepartum diet treatment (DIET); season (SEA; 1 = cows with dry periods during hotter months [September, October, March, April, May] and 2 = cows with dry periods during cooler months [November, December, January, and February]); all of their interactions, using cow(TRT $\times$ $\mathrm{DRY} \times \mathrm{DIET} \times \mathrm{SEA}$ ) as the error term; as well as weeks or days to the highest order significant for overall prepartum and postpartum periods, as appropriate.

\section{RESULTS}

\section{Changes in BW and BCS}

Prepartum. No effects of bST treatment, dry period treatment, season, or diet were detected for BW or BCS 


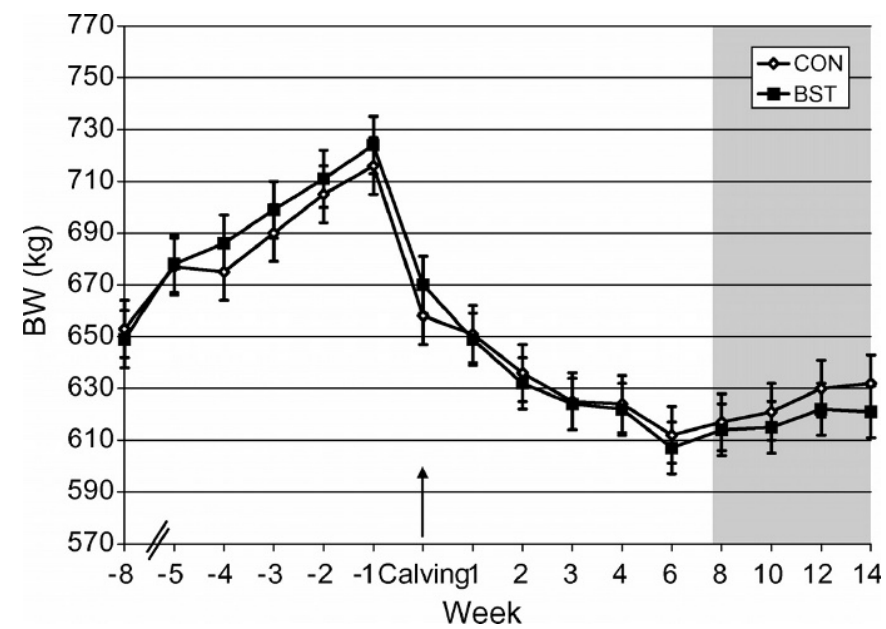

Figure 1. Least squares means and SE for BW of Holstein cows during the prepartum and early postpartum periods ( -8 wk through $14 \mathrm{wk}) . \mathrm{CON}=$ Control group; bST = bST-injected group $(10.2 \mathrm{mg} /$ d). Shaded area indicates the time full doses of bST were injected (500 mg/14 d). Arrow indicates calving.

during the prepartum period. However, the interaction of diet and season was significant for BW $(P<0.04)$ and BCS $(P<0.06)$, and the interaction of season and dry period treatment was significant for BCS $(P<0.04)$. A quadratic effect of week was detected for BW $(P<$ $0.01)$ and for BCS $(P<0.05)$. The mean prepartum BW of cows in the control and bST treatment groups were 682 and $688 \mathrm{~kg}$. Cows in both groups gained BW from $-8 \mathrm{wk}$ to $-1 \mathrm{wk}$ (Figure 1 ). At $-8 \mathrm{wk}$, cows in the control group weighed only $4 \mathrm{~kg}$ more than cows in the bST treatment group. During the final week before calving BW for control and bST-treated cows were 9 and $10 \%$ greater than at $-8 \mathrm{wk}$, and mean prepartum BCS for the same treatment groups followed the same pattern (Table 2; Figure 2). No differences were observed in mean BCS of cows in the control and bST treatment groups at $-8 \mathrm{wk}$ (3.28 for both groups). The BCS of both groups increased during prepartum period with highest $\mathrm{BCS}$ at $1 \mathrm{wk}$ before calving (control $=3.50$ and $\mathrm{bST}=$ $3.55 ; P<0.05)$.

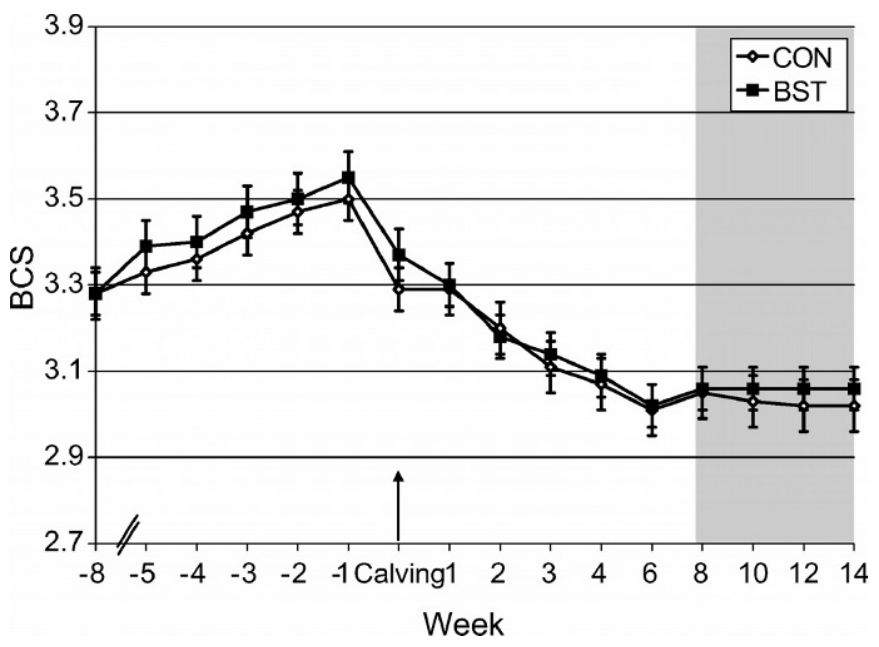

Figure 2. Least squares means and SE for BCS of Holstein cows during the prepartum and early postpartum periods ( $-8 \mathrm{wk}$ through $14 \mathrm{wk})$. CON = Control group; bST = bST-injected group $(10.2 \mathrm{mg} /$ d). Shaded area indicates the time full doses of bST were injected $(500 \mathrm{mg} / 14 \mathrm{~d})$. Arrow indicates calving.

Postpartum. No effects of bST treatment, dry period treatment, diet, or season were observed for BW during the early postpartum period (wk 1 to 14 ). However, an interaction of season and diet $(P<0.08)$ and a cubic effect of week on BW $(P<0.01)$ were detected. No effects of bST treatment, diet, or season were observed for BCS during the same period. However, for postpartum BCS, effects of dry period treatment $(P<0.04)$ and a cubic effect of week $(P<0.01)$ were detected. Birth weights of calves in the control and bST groups did not differ $(36.5 \pm 1.2$ vs. $38.3 \pm 1.2 \mathrm{~kg} ; P=0.42)$.

Mean BW decreased sharply after parturition in both the bST and control groups (Figure 1), as expected, but did not differ between these groups. During the overall postpartum period, mean changes in BW did not differ between the bST and control treatments (Table 2). The decrease in BW was observed up to 6 wk postpartum. After this time, cows in both the bST and control groups maintained their BW (Figure 1; Table 2). No differences were detected in mean BCS of cows in the control and

Table 2. Least squares means and SE for BCS, BW, and DMI during prepartum and postpartum periods for Holstein cows injected or not injected with bST.

\begin{tabular}{|c|c|c|c|c|}
\hline & \multicolumn{2}{|c|}{ Prepartum ( -28 to $-1 \mathrm{~d})$} & \multicolumn{2}{|c|}{ Postpartum (0 to $28 \mathrm{~d})$} \\
\hline & \multicolumn{2}{|c|}{ bST Treatment ${ }^{1}$} & \multicolumn{2}{|c|}{ bST Treatment ${ }^{1}$} \\
\hline & 1 & 2 & 1 & 2 \\
\hline $\mathrm{BW}, \mathrm{kg}$ & $682.4 \pm 10.4$ & $688.5 \pm 11.4$ & $628.0 \pm 10.3$ & $622.9 \pm 9.4$ \\
\hline $\mathrm{BCS}$ & $3.38 \pm 0.05$ & $3.42 \pm 0.05$ & $3.10 \pm 0.05$ & $3.11 \pm 0.05$ \\
\hline DMI, kg/d & $15.8 \pm 0.55$ & $16.4 \pm 0.54$ & $25.7 \pm 0.76$ & $25.9 \pm 0.75$ \\
\hline
\end{tabular}

${ }^{1}$ Treatment $1=$ no bST; treatment $2=10.2 \mathrm{mg}$ of bST/d beginning $\mathrm{d}-21$. 


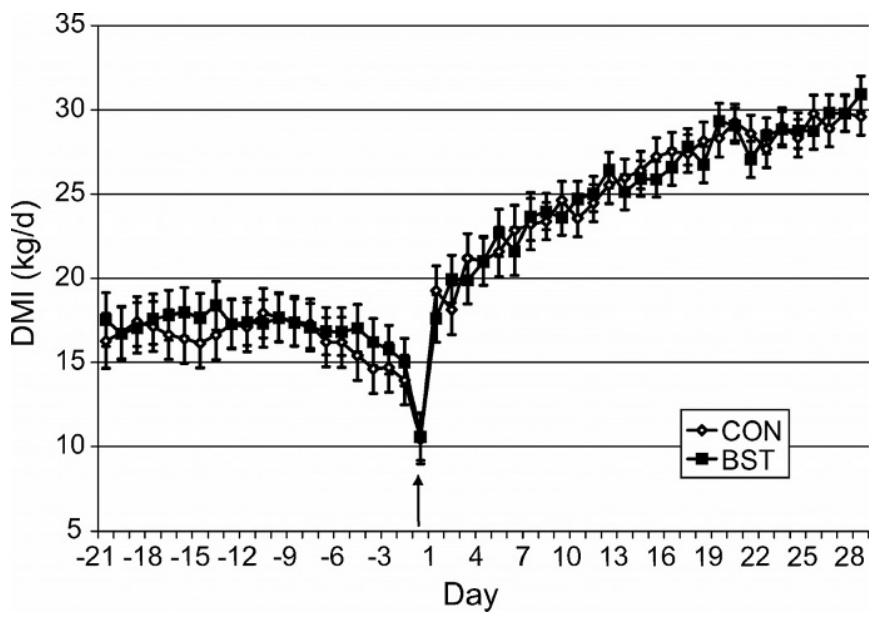

Figure 3. Dry matter intake of Holstein cows during the prepartum and early postpartum periods $(-21$ through $28 \mathrm{~d})$. CON $=$ Control group; bST = bST-injected group $(10.2 \mathrm{mg} / \mathrm{d})$. Arrow indicates calving.

bST groups following parturition. Changes in BCS generally followed the same pattern as BW, as the decrease also continued until about 6 wk postpartum but thereafter remained slightly above 3.0 for cows in both the bST and control groups (Figure 2; Table 2). The BW and BCS during the postpartum period were positively correlated $(P<0.001 ; \mathrm{r}=0.58)$.

\section{Changes in DMI}

Prepartum. During the prepartum period ( -21 to -1 d), no differences were detected in DMI between the bST and control groups, the dry period treatments, or the diet treatments. However, cubic effects of days $(P$ $<0.01)$ and quadratic effects of BCS $(P<0.01)$ were detected. Least squares means for DMI during the overall prepartum period are presented in Table 2. Mean DMI at $3 \mathrm{wk}$ prepartum was greater than $16 \mathrm{~kg} / \mathrm{d}$ for cows in both the control and bST treatment groups, but they did not differ. No decrease in DMI was observed through $8 \mathrm{~d}$ before calving (DMI $\sim 17 \mathrm{~kg} / \mathrm{d}$ for cows in both groups; Figure 3 ). However, decline in DMI tended to be slightly sharper for cows in the control group during the week prior to calving; at $2 \mathrm{~d}$ before calving, DMI was $\sim 14 \mathrm{~kg}(-18 \%)$, whereas it was $\sim 15 \mathrm{~kg} / \mathrm{d}(-12$ $\%$ ) for cows in the bST group. One day before calving, DMI was about $10 \mathrm{~kg}$ for cows in both the control and bST groups. Reduction in DMI was about $40 \%$ from d 8 to 1 prepartum for cows in both the bST and control groups (Figure 3).

Postpartum. During the postpartum period (0 to 28 d), no differences in DMI attributable to bST treatment, dry period treatment, or diet treatment were detected, but effects of season were significant $(P<0.04)$. Cows in both the control and bST groups showed increased DMI after parturition. As expected, cows had their lowest DMI $(\sim 17 \mathrm{~kg} / \mathrm{d})$ the day following calving, but it increased gradually thereafter, and, by $1 \mathrm{wk}$ after calving, the DMI had increased about 35\% to $23 \mathrm{~kg} / \mathrm{d}$ (Figure 3 ). At the end of the measurement period (d 28), mean DMI for the cows in both the bST and control groups was $\sim 30 \mathrm{~kg} / \mathrm{d}$ (Figure 3 ). The DMI was correlated positively with BW $(P<0.025 ; \mathrm{r}=0.05)$ but not with BCS $(P<0.25 ; \mathrm{r}=0.03)$ during 0 to $28 \mathrm{~d}$ postpartum.

\section{Hormones, Growth Factor, and Metabolites}

Prepartum. Least squares means and SE for all blood plasma and serum variables during the overall prepartum period (from $\mathrm{d}-21$ to -1 ) are presented in Table 3. Mean concentrations of somatotropin during the overall prepartum period were greater in bSTtreated cows than in control cows $(8.19 \mathrm{vs.} .51 \mathrm{ng} / \mathrm{mL} ; P$ $<0.01$ ), and increased concentrations were maintained throughout the prepartum period (Figure 4).

Mean concentrations of IGF-I during $3 \mathrm{wk}$ prepartum differed because of bST treatment $(P<0.01)$. Cows treated with bST had greater mean plasma concentrations of IGF-I than did cows in the control group (318.8 vs. $235.2 \mathrm{ng} / \mathrm{mL} ;+35.5 \%$ ). As expected, overall plasma concentrations of IGF-I decreased progressively from d -21 to parturition in both the bST and control groups (Figure 5), but mean concentrations on $d-1$ were still $52 \%$ greater in cows treated with bST than in control cows (244.2 vs. 160.7), even though overall decreases were 31.7 and $23.7 \%$ compared with d -21 . Mean concentrations of insulin also were greater $(24.7 \% ; P<0.02)$ in cows treated with bST during the overall prepartum period (0.85 vs. $1.06 \mathrm{ng} / \mathrm{mL}$; Table 3). However, concentrations of insulin declined in both groups as they approached calving, but they remained less for cows in control group throughout the prepartum period (Figure 6).

Although overall prepartum mean concentrations of glucose did not differ because of bST treatment (Table 3 ), plasma concentrations of glucose increased significantly at d-14 in bST-treated cows and tended to be greater until calving (Figure 7). The increase in mean plasma concentrations of glucose for cows in the bST group at $d-1$ were about $6.4 \%$ greater than at $d-11$ $(P<0.01)$.

Considering the overall prepartum period (from d -21 to -1), mean concentrations of NEFA in plasma did not differ between cows in the control and bST groups (Table 3). Although mean plasma concentrations of NEFA were similar during the prepartum period, significant increases were observed for cows in both the bST and control groups beginning $3 \mathrm{~d}$ prepartum, with 
Table 3. Least squares means and SE for concentrations of hormones, growth factor, and metabolites in plasma of Holstein cows injected or not injected with bST (d -21 to 28).

\begin{tabular}{|c|c|c|c|c|}
\hline \multirow[b]{3}{*}{ Blood measures } & \multicolumn{2}{|c|}{ Prepartum $(-21$ to $-1 \mathrm{~d})$} & \multicolumn{2}{|c|}{ Postpartum (0 to $28 \mathrm{~d})$} \\
\hline & \multicolumn{2}{|c|}{ bST Treatment ${ }^{1}$} & \multicolumn{2}{|c|}{ bST Treatment ${ }^{1}$} \\
\hline & 1 & 2 & 1 & 2 \\
\hline $\mathrm{ST},{ }^{2} \mathrm{ng} / \mathrm{mL}$ & $5.51^{\mathrm{a}} \pm 0.48$ & $8.19 \pm 0.52$ & $5.52^{\mathrm{a}} \pm 0.36$ & $10.33 \pm 0.40$ \\
\hline $\mathrm{INS},{ }^{2} \mathrm{ng} / \mathrm{mL}$ & $0.85^{\mathrm{b}} \pm 0.05$ & $1.06 \pm 0.06$ & $0.62 \pm 0.05$ & $0.58 \pm 0.04$ \\
\hline IGF-I, ng/mL & $235.2^{\mathrm{a}} \pm 7.6$ & $318.8 \pm 8.4$ & $117.4^{\mathrm{a}} \pm 6.9$ & $150.2 \pm 7.7$ \\
\hline Glucose, $\mathrm{mg} / \mathrm{dL}$ & $69.3 \pm 1.0$ & $71.6 \pm 1.0$ & $61.9 \pm 0.8$ & $62.1 \pm 0.8$ \\
\hline NEFA, $\mu \mathrm{Eq} / \mathrm{L}$ & $265.0 \pm 14.3$ & $273.5 \pm 15.3$ & $582.4 \pm 40.8$ & $634.2 \pm 45.1$ \\
\hline
\end{tabular}

${ }^{1}$ Treatment $1=$ no bST; treatment $2=10.2 \mathrm{mg}$ of bST/d through $42 \pm 2 \mathrm{~d}$ postpartum..

${ }^{2} \mathrm{ST}=$ somatotropin and INS = insulin.

${ }^{\text {a }} P<0.01$ (Comparisons are only appropriate within the prepartum or within the postpartum treatments).

${ }^{\mathrm{b}} P<0.02$ (Comparisons are only appropriate within the prepartum or within the postpartum treatments).

the greatest mean concentrations around calving (Figure 8).

Postpartum. No differences in mean concentrations of somatotropin, IGF-I, insulin, glucose, or NEFA were observed during the overall postpartum period for cows relative to the dry period treatments or diets. However, the two-factor interaction of bST treatment and dry period treatment was significant for both insulin $(P<$ $0.06)$ and NEFA $(P<0.01)$. Mean concentrations of somatotropin in control and bST-treated cows differed during the first 4 wk postpartum (Table $3 ; P<0.01$ ). Concentrations of somatotropin in plasma of cows in

Table 4. Least squares means and SE for milk yield, 3.5\% FCM yield, and SCC of Holstein cows during early lactation.

\begin{tabular}{|c|c|c|}
\hline \multirow[b]{2}{*}{ Measurement } & \multicolumn{2}{|c|}{ bST Treatment $^{1}$} \\
\hline & 1 & 2 \\
\hline 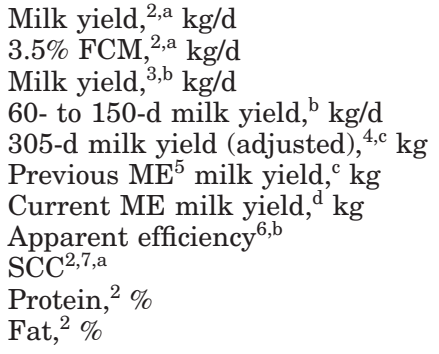 & $\begin{aligned} 37.7 & \pm 1.07 \\
38.2 & \pm 1.04 \\
38.0 & \pm 0.49 \\
37.1 & \pm 0.51 \\
9512 & \pm 266 \\
10423 & \pm 254 \\
9420 & \pm 284 \\
1.06 & \pm 0.01 \\
527 & \pm 39.0 \\
2.86 & \pm 0.01 \\
3.93 & \pm 0.03\end{aligned}$ & $\begin{aligned} 41.6 & \pm 1.23 \\
41.2 & \pm 1.19 \\
40.1 & \pm 0.56 \\
40.4 & \pm 0.60 \\
10071 & \pm 276 \\
10588 & \pm 283 \\
10076 & \pm 317 \\
1.21 & \pm 0.02 \\
323 & \pm 43.0 \\
2.87 & \pm 0.01 \\
3.96 & \pm 0.03\end{aligned}$ \\
\hline $\begin{array}{l}{ }^{1} \text { Treatment } 1=\text { no bST; treatm } \\
42 \pm 2 \text { d postpartum. } \\
{ }^{2} \text { During wk } 1 \text { to } 10 \text { postpartum } \\
{ }^{3} \text { During wk } 1 \text { to } 21 \text { postpartum } \\
{ }^{4} \text { Adjusted for previous actual } 3 \\
{ }^{5} \mathrm{ME}=\text { mature equivalent. } \\
{ }^{6} \text { During wk } 1 \text { to } 4 \text { postpartum. } \\
{ }^{7} \times 1000 . \\
{ }^{a} P<0.05 . \\
{ }^{\mathrm{b}} P<0.03 . \\
{ }^{\mathrm{c}} P<0.09 . \\
{ }^{\mathrm{d}} P<0.1 .\end{array}$ & -d milk yield. & $\mathrm{bST} / \mathrm{d}$ through \\
\hline
\end{tabular}

the control group were about one-half of those of cows in the bST group (5.52 vs. $10.33 \mathrm{ng} / \mathrm{mL}$ ). Mean concentrations of somatotropin in bST-treated cows were about $87 \%$ greater throughout the early postpartum period (Figure 4), largely because concentrations of somatotropin in cows in the control group remained essentially constant throughout the 28 -d period.

Cows in both groups had greater plasma concentrations of IGF-I prepartum, and they remained essentially at calving levels during the first $2 \mathrm{wk}$ postpartum (Figure 5). Mean concentrations of IGF-I during the overall postpartum period also were greater in cows in the bST group than in the control group (150.2 vs. 117.4 $\mathrm{ng} / \mathrm{mL}$; Table 3 ), and they were maintained at a greater level (+27.9\%) throughout the early postpartum period (d 1 to 28 ).

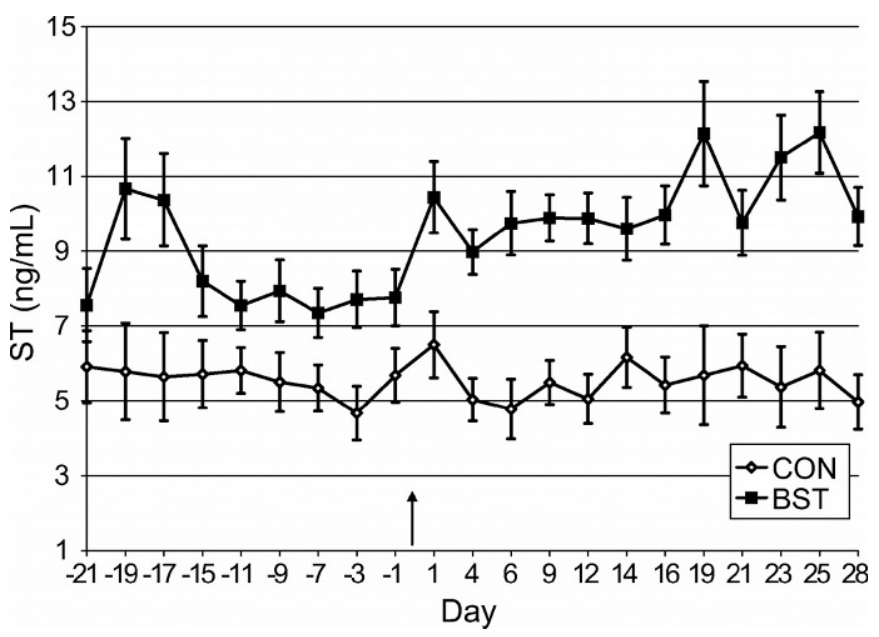

Figure 4. Least squares mean concentrations of somatotropin (ST) in plasma during the transition period $(-21 \mathrm{~d}$ through $28 \mathrm{~d})$. CON = Control group; bST $=$ bST-injected group $(10.2 \mathrm{mg} / \mathrm{d})$. Arrow indicates calving. 


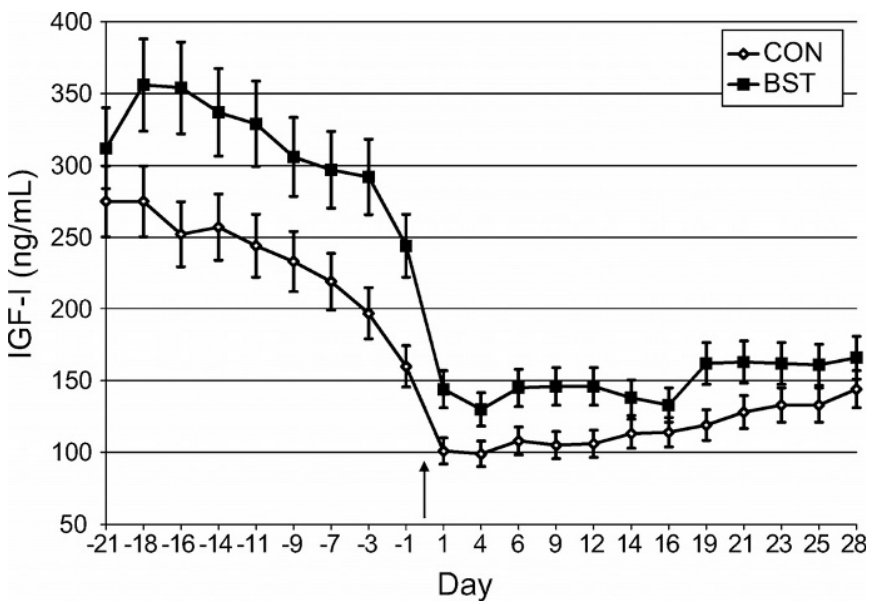

Figure 5. Least squares mean concentrations of IGF-I in plasma during the transition period $(-21 \mathrm{~d}$ through $28 \mathrm{~d})$. CON $=$ Control group; bST = bST-injected group $(10.2 \mathrm{mg} / \mathrm{mL})$. Arrow indicates calving.

Mean concentrations of insulin in plasma during the early postpartum period did not differ between bST treatment groups (control vs. bST $=0.62$ vs. $0.58 \mathrm{ng} /$ $\mathrm{mL}$ ). Plasma concentrations tended to decline further during the 1st wk postpartum, but there was a slight increase during the remainder of the 28 -d postpartum period (Table 3; Figure 6). Concentrations of glucose in plasma followed a trend similar to insulin, and no differences were observed in mean plasma concentrations after calving between cows in the control and bST treatment groups (Figure 7). However, concentrations in both the control and bST treatment groups decreased during first 2 wk postpartum and then increased

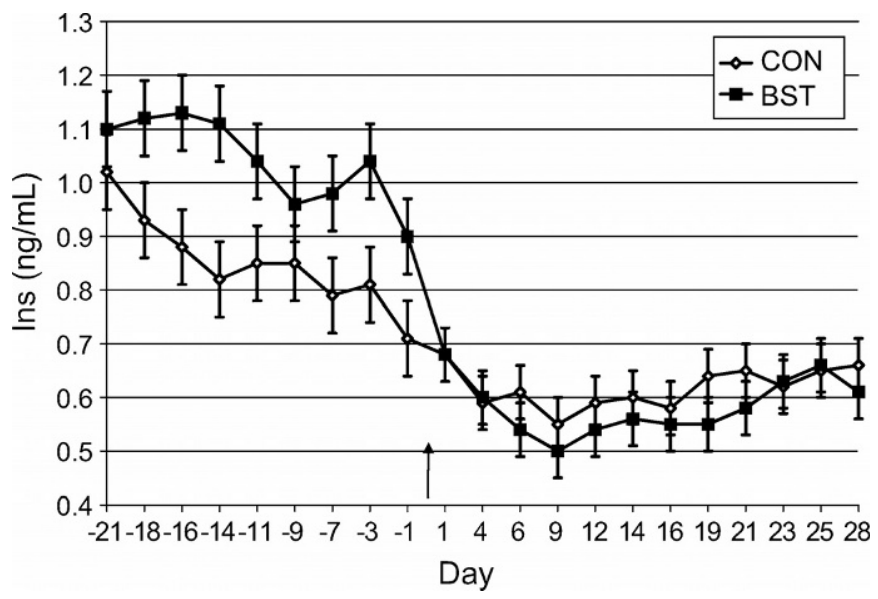

Figure 6. Least squares mean concentrations of insulin (Ins) [Au: verify.] in plasma during the transition period ( $-21 \mathrm{~d}$ through 28 d). $\mathrm{CON}=$ Control group; bST = bST-injected group $(10.2 \mathrm{mg} / \mathrm{d})$. Arrow indicates calving.

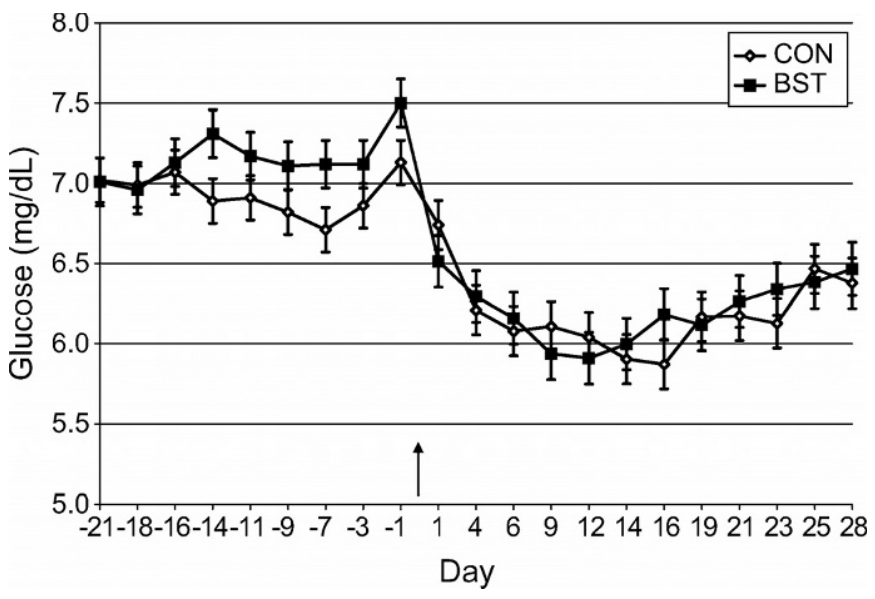

Figure 7. Least squares mean concentrations of glucose in plasma during the transition period $(-21 \mathrm{~d}$ through $28 \mathrm{~d})$. $\mathrm{CON}=$ Control group; bST = bST-injected group $(10.2 \mathrm{mg} / \mathrm{d})$. Arrow indicates calving.

slightly during the final 2 wk of the 4-wk sampling period (Figure 7). Overall, postpartum concentrations of glucose in plasma were less than those prepartum $(P<0.01)$.

Mean concentrations of NEFA during the early postpartum period are presented in Table 3. Plasma concentrations of NEFA for cows in both the control and bST treatment groups followed the same trend, and no differences were observed between cows in the control and bST groups (584.3 vs. $634.2 \mu \mathrm{Eq} / \mathrm{L}$ ). Concentrations were greatest around the time of calving and remained greater across both the control and bST groups during the 1st wk following calving; for cows in the bST group, concentrations remained greater during the 2 nd wk. Thereafter, NEFA concentrations decreased continu-

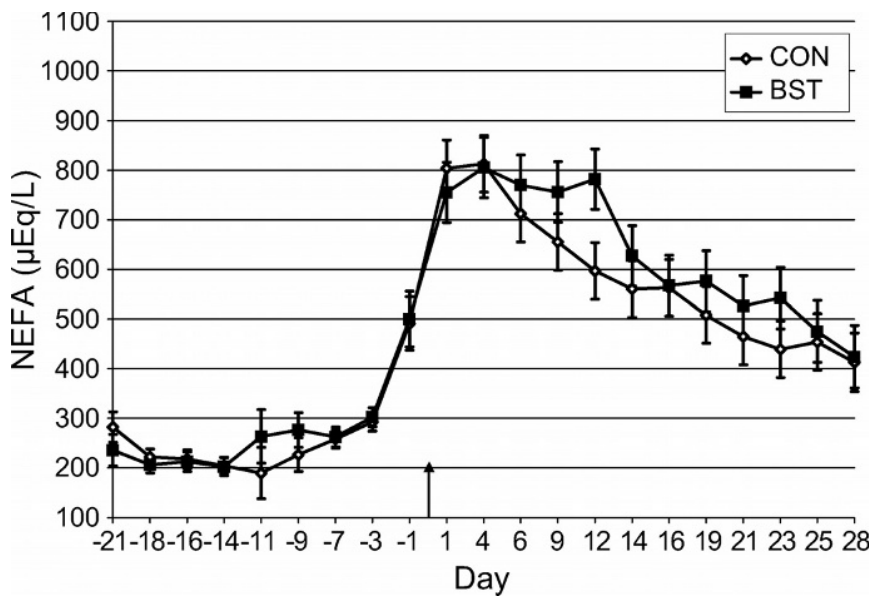

Figure 8. Least squares mean concentrations of NEFA in plasma during the transition period $(-21 \mathrm{~d}$ through $28 \mathrm{~d})$. CON $=$ Control group; bST = bST-injected group $(10.2 \mathrm{mg} / \mathrm{d})$. Arrow indicates calving. 


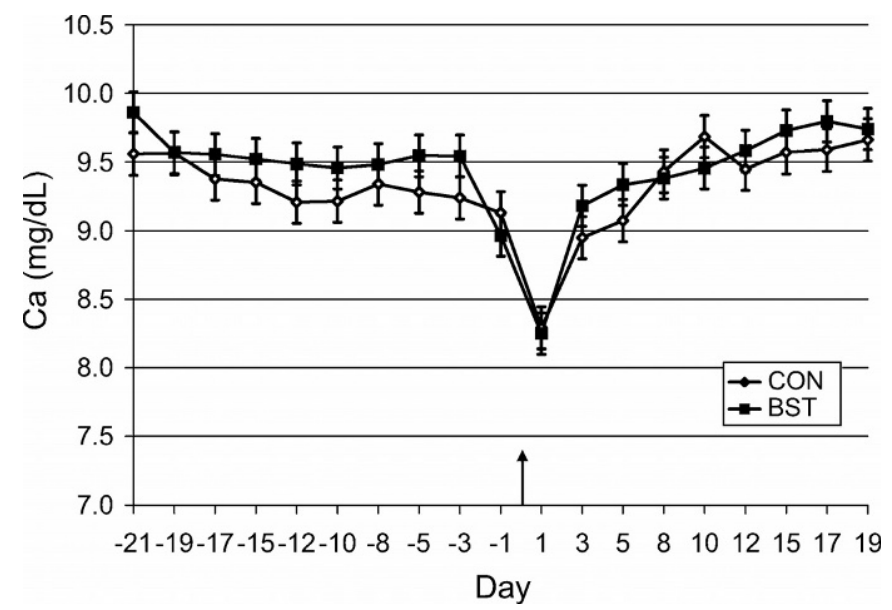

Figure 9. Serum concentrations of $\mathrm{Ca}$ in Holstein cows during the prepartum and postpartum periods. $\mathrm{CON}=$ Control group; $\mathrm{bST}=$ bST-injected group $(10.2 \mathrm{mg} / \mathrm{d})$. Arrow indicates calving.

ously throughout the remainder of the 4-wk sampling period (Figure 8).

\section{Serum Ca Concentrations}

Concentrations of $\mathrm{Ca}$ in serum did not differ because of bST treatment, dry period treatment, diet, or season. Overall, serum concentrations declined around parturition and were least on the day following calving (Figure 9). However, only 16 of 80 cows had serum concentrations of Ca less then $7 \mathrm{mg} / \mathrm{dL}$ on the day following calving, and 11 of those 16 were in the control group. Mean concentrations of $\mathrm{Ca}$ during the 4 -wk interval

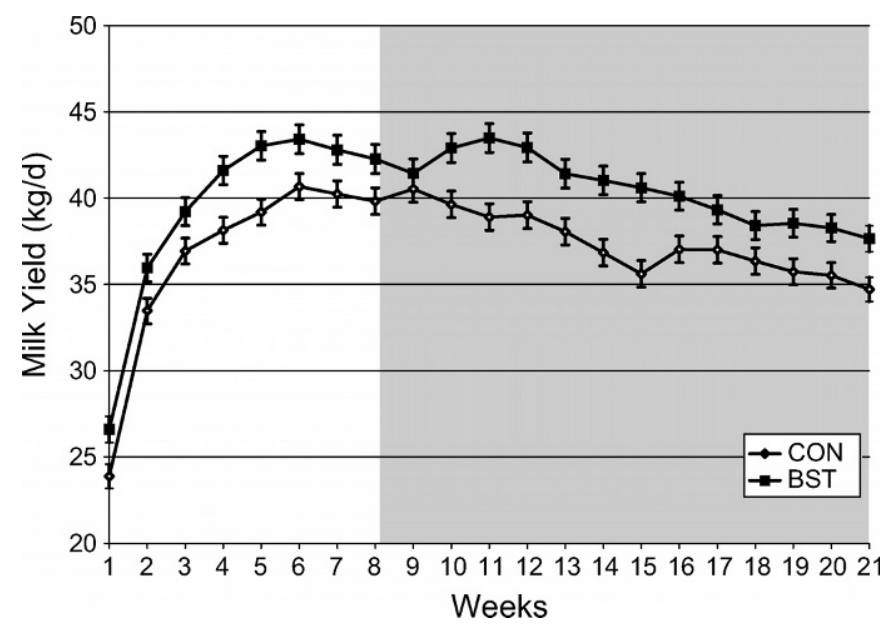

Figure 10. Least squares means and SE for daily milk yields and $\mathrm{SE}$ of Holstein cows during the first 21 wk of lactation. Shaded area indicates the time full doses of bST were injected $(500 \mathrm{mg} / 14 \mathrm{~d})$. $\mathrm{CON}=$ Control group; bST $=$ bST-injected group $(10.2 \mathrm{mg} / \mathrm{d})$. from 2 wk before through 2 wk after calving were 9.41 and $9.28 \mathrm{mg} / \mathrm{dL}$ in control and bST-treated cows.

\section{MY and 3.5\% FCM Yield}

There were greater MY and 3.5\% FCM yields for bSTtreated cows during first 10 wk postpartum $(P<0.05)$, and an effect of supplemental bST was detected for the overall lactation period ( $21 \mathrm{wk})$ for $\mathrm{MY}(P<0.03$; Table 4). Greater MY from cows in the bST group persisted after all cows received the full dose of bST during 60 to 150 DIM (500 mg of bST/14 d; $P<0.03$; Figure 10). No differences were observed in percentages of protein (2.86\% vs. $2.87 \%)$ or fat (3.93\% vs. $3.96 \%)$ between cows in control and bST groups. However, cows in the control group had greater SCC (62\%) than did cows in the bST group during the first $10 \mathrm{wk}$ of lactation $(P<0.05$; Table 4). No differences were detected because of dry period treatment or diet for MY or 3.5\% FCM yields during first $10 \mathrm{wk}$ or during the overall lactation period (wk 1 to 21$)$.

Apparent efficiency of milk production ( $\mathrm{kg}$ of milk/ $\mathrm{kg}$ of DMI) for cows in the control and bST groups (Table 4) differed (bST group $=1.21 \mathrm{vs}$. control group $=1.06$; $P<0.03)$. The 305-d mature equivalent (ME) MY of cows during the previous lactation did not differ between the control and bST groups $(10,588 \pm 283$ vs. $10,423 \pm 254$ $\mathrm{kg}$; Table 4). However, the 305-d ME yields from bSTtreated cows tended to be greater than those from control cows $(10,076 \pm 317 \mathrm{vs.} 9420 \pm 284 \mathrm{~kg} ; P<0.09$; Table 4). Similarly, the 305-d ME MY adjusted for previous actual 305-d MY also tended to be greater for cows in the bST group than for cows in the control group (10,071 \pm 276 vs. $9512 \pm 266 \mathrm{~kg} ; P<0.09$; Table 4 ).

\section{DISCUSSION}

An important finding of this study was that bST supplementation prepartum and through the first $8 \mathrm{wk}$ of lactation tended to increase MY and 3.5\% FCM yields. The greater MY of the bST cows was sustained or even increased after cows in both groups received a full dose of bST (POSILAC) beginning at $56 \pm 2$ DIM. The positive response to bST supplementation postpartum was apparent through 150 DIM. Although bST-supplemented cows showed greater MY after initiating the full dose of bST at about the recommended time ( $\sim 56$ DIM), the difference in milk production observed from 8 to 21 wk of lactation apparently was not because of other management practices. Cows in both groups were managed together in the same free-stall barns and groupfed the same TMR throughout the first 150 DIM. Importantly, no additional treatments, other than those described and accounted for in statistical analyses, 
were imposed on these cows during this time period, and any effects of season of calving had been accounted for.

Typically, biweekly doses of bST (POSILAC) give MY responses of about $15 \%$ ( 4 to $6 \mathrm{~kg} / \mathrm{d})$. Actual and percentage increases can be much greater when greater doses of bST are injected. Mean increases observed in MY and 3.5\% FCM yields in the current study were about $6.6 \%$ when low doses of bST were given prepartum and during early lactation. The daily dose of bST used was about $29 \%$ of the amount of bST in the full dose. However, the MY of cows in the bST group following the initiation of the full dose of bST injections increased to 8 to $11 \%(\sim 3$ to $4 \mathrm{~kg} / \mathrm{d})$ over that of control cows. Thus, there was a slightly greater increase in the difference in MY between bST-treated cows and control cows compared with that observed when the lower doses were injected. However, this still was slightly less than expected for the full dose. Nonetheless, MY and 3.5\% FCM yield responses to low doses of bST in the current study agreed with previous results where low doses had been used (Gulay, 1998, 2002; Gulay et al., 2000, 2003b).

A major difference in the study of Gulay et al. (2003b) was that they discontinued supplementation of bST after $7 \mathrm{wk}$ of lactation, and the increase in MY did not persist after bST was discontinued. Therefore, no positive residual effects of prepartum and early lacation injections of low doses of bST on MY were observed beyond $7 \mathrm{wk}$ (Gulay et al., 2003b). One interpretation is that perhaps activity and/or numbers of mammary epithelial cells were better maintained or even enhanced when the low doses of bST were followed by the full dose of bST. This interpretation is made with caution because it is based wholly on MY responses observed in current and previous studies where cows had been managed and fed similarly, but where no direct measures of cell numbers or activity actually were obtained.

The mechanism by which bST directly or indirectly affects mammary gland function likely involves the somatotropin-IGF-I axis and DMI. More specifically, this involves the relative increase in peripheral concentrations of somatotropin and IGF-I, energy balance of the cows, and perhaps effects on mammary epithelial cell activity and/or numbers. Administration of bST increases circulating concentrations of IGF-I and IFGBP3 , which parallel the increase in MY, and there is a decrease in IGFBP-2 (Bauman and Vernon, 1993). One important effect mediated by IGF-I is increased cell proliferation (Rechler and Nissley, 1990), which is seen in cultured mammary cells obtained from both pregnant and lactating cows (Baumrucker and Stemberger, 1989). Thus, increased concentrations of IGF-I in bST- treated cows during the prepartum and postpartum periods might have had positive effects on cell numbers via either epithelial cell proliferation, or maintenance, or both during these periods. Results of Putnam et al. (1999), that prepartum injections of a full dose of bST beginning at $\mathrm{d}-28$ enhanced MY, also can be interpreted in this way. If this occurred, then the increase in secretory cell numbers could have been responsible, in part, for the greater MY when activity of these cells was further enhanced by the full dose of bST. Clearly, positive effects of bST on mammary epithelial cell proliferation, maintenance, and activity need to be verified by direct measures.

High DMI caused by greater bST supplementation $(>56$ DIM) would have provided the additional nutrients needed to support greater MY without further increasing extent of tissue mobilization. Thus, BW and BCS would not have been affected differently in bST-treated and control cows. Essentially, this is what has been shown in a series of studies where low doses of bST have been injected prepartum, during early lactation, or both (Gulay, 1998; Stanisiewski et al., 1992; Gulay et al., 2003b). The ability of injected cows to achieve good DMI and better maintenance of BW and BCS during these periods of injection appears to be an important response to low doses of bST $(10.2 \mathrm{mg} / \mathrm{d})$. In fact, BCS and BW were similar throughout the postpartum period in both control and bST-treated cows, and DMI showed rapid and similar rates of increase in both groups through 28 DIM. This result supports the interpretation that the extra energy to support increased MY arose from greater DMI rather than from greater mobilization of body reserves. Indeed, DMI was relatively high across both bST and control groups; plus, there was a $14 \%$ increase in the apparent efficiency of MY in bST-treated cows during the first 28 DIM. These changes allowed cows to maintain their BW and BCS better while MY rapidly increased. Changes in BW during the latter portion of the dry period likely reflected fetal development, and neither BW nor BCS of cows in the bST or control groups were affected appreciably on a week-to-week basis or by the small decline in DMI during the final week prepartum or by the more substantial decrease around the day of calving.

Variable positive or negative responses have been observed in various studies following prepartum and early postpartum injections of bST (Gallo and Block, 1990; de Boer et al., 1991; Remond et al., 1991; Stanisiewski et al., 1992; Simmons et al., 1994; Eppard et al., 1996; Moallem et al., 1997; Schneider et al., 1989; Moallem et al., 2000). For example, no increase in MY was observed when Holstein or Jersey cows were injected with a full dose of bST (POSILAC) during the prepartum period (Eppard et al., 1996). Latter results 
might have occurred because cows also were used for milk fever induction, but plasma concentrations of somatotropin and IGF-I in bST-injected cows also did not differ from control cows. In contrast, Putnam et al. (1999) injected cows with a full dose of bST beginning at $28 \mathrm{~d}$ prepartum through calving and reported a 3.3$\mathrm{kg} / \mathrm{d}$ increase in MY through 42 DIM, but they also reported variable effects of bST on milk composition. Early postpartum treatment of dairy cows (beginning $14 \mathrm{DIM}$ ) with 5 or $14 \mathrm{mg}$ of bST/d stimulated an approximate 6\% increase in FCM yield (Stanisiewski et al., 1992). Richard et al. (1985) also reported an approximate 6\% increase in MY when cows were injected with $50 \mathrm{IU}$ of bST starting at $20 \mathrm{~d}$ postpartum, but they reported a $25 \%$ increase in milk fat. No increases in DMI or efficiency of milk production were detected when cows were injected with bST during early lactation (Schneider et al., 1989; Gallo and Block, 1990). Moreover, postpartum DMI of cows injected with lesser doses of bST ( 5 and $14 \mathrm{mg}$ of bST/d) during the prepartum period did not differ (Simmons et al., 1994). Furthermore, when cows were injected with $20.6 \mathrm{mg}$ of $\mathrm{bST} / \mathrm{d}$ (de Boer et al., 1991) or 5 and $14 \mathrm{mg}$ of bST/d (Stanisiewski et al., 1992), postpartum DMI and BW (de Boer et al., 1991) or BCS (Stanisiewski et al., 1992) were not affected.

Although fat and protein percentages in milk of cows in the control and bST groups did not differ in the current study, it was interesting that cows in the bST group had lower SCC in milk than did cows in the control group. There is a slight increase in mastitis in lactating cows treated with bST, but this increase is associated primarily with the increased MY, and increased MY usually is associated with increases in SCC in milk (White et al., 1994). Several researchers have suggested that somatotropin may have a potential role in preventing mastitis in ruminants and in their ability to recover more quickly from experimentally induced mastitis (Vandeputte-Van Messom and Burvenich, 1993; Burvenich et al., 1999; Hoeben et al., 1999). However, beneficial effects were limited to severe mastitis (Burvenich et al., 1999), indicating that somatotropin may protect the blood-milk barrier and restore the integrity of the tight junctions in the mammary epithelium of an inflamed mammary gland. It is not known if effects on SCC detected are associated with reduced incidence of mastitis during early lactation.

In previous (Gulay et al., 2000, 2003b) and current studies, injecting low doses of $\mathrm{bST}(\geq 10.2 \mathrm{mg} / \mathrm{d})$ resulted in a rapid and sustained increase in concentrations of somatotropin in the peripheral circulation of injected cows. The amount chosen (10.2 $\mathrm{mg}$ of $\mathrm{bST} / \mathrm{d})$ to inject during the current study was based on findings of Gulay (1998) that this dose was the lowest one of those evalu- ated that brought about desired and presumably beneficial effects on somatotropin and IGF-I. Thus, the increase in plasma concentrations of somatotropin in the current study was expected. The magnitude of increase in mean concentrations of somatotropin seems appropriate for the amount of bST injected prepartum and/ or postpartum considering the thrice weekly blood sampling pattern relative to the biweekly schedule of bST injections. Even though the same blood sampling pattern was used prepartum and postpartum for all cows, overall mean concentrations of somatotropin tended to be greater during the postpartum period, but only in bST-injected cows. Changes in concentrations of somatotropin following injections of bST have been seen over a wide range of injection doses and times within the lactation cycle (Bachman et al., 1992; Lucy et al. 1993; Simmons et al., 1994). Additional changes observed included prepartum and postpartum increases in IGF-I and prepartum, but not postpartum, increases in insulin.

In general, cows in the bST group had greater concentrations of IGF-I during both the prepartum and postpartum periods, although the increase in IGF-I concentrations after parturition was slightly less than occurred prepartum $(\sim 36 \%$ vs. $\sim 28 \%)$. These results probably reflected the known association between IGFI concentrations and the decrease in energy and specific nutrient intake because of reduced DMI around calving. Synthesis and secretion of IGF-I in response to somatotropin is affected by energy balance (Ronge et al., 1988; Elsasser et al., 1989; Phillips et al., 1990), and the somatotropin-IGF-I axis is attenuated by nutritional status (Bauman and Vernon, 1993). The greatest response to bST treatments was observed when cows were fed high-protein, high-energy diets (McGuire et al., 1992), diets that typically are fed to cows during early lactation. This may explain, in part, the reason for slightly greater concentrations of IGF-I postpartum in the bST-injected cows. Vicini et al. (1991) also detected a greater increase in concentrations of IGF-I during late lactation and the dry period, times when relative DMI was greater than apparent needs. Overall, changes in concentrations of somatotropin and IGF-I indicate the ability of somatotropin to stimulate increase in IGF-I production by liver, albeit somewhat reduced, during the transition period, even when the somatotropin receptor (GHR-1A) involved in this action may be reduced (Lucy et al., 2001).

Insulin is another hormone associated with energy balance (storage and mobilization) and MY. It has wellknown effects on glucose metabolism and, along with somatotropin, affects mobilization and storage of lipids in adipose tissue. Concentrations of insulin in the current study were greater during the prepartum period 
because all cows were in positive energy balance. They also had greater peripheral concentrations of glucose (Figure 7), as previously shown (Vicini et al., 1991; Bachman et al., 1992; Lucy et al., 1993). As cows approach calving, concentrations of insulin and glucose typically decline. Further decline in concentrations of insulin are expected after parturition, and they remain reduced throughout early lactation (1 to 28 DIM). Thus, results for insulin were as expected, whether bST was injected or not. Increased concentrations of insulin in plasma during the dry period are associated with positive energy balance of the cows, which results in greater concentrations of glucose in blood during the dry period. Decreased concentrations after parturition likely occurred because of the rapid onset of the NEB during early lactation (Vicini et al., 1991), as lactation demands for energy and precursors for milk synthesis rapidly increased.

Treatment of cows with bST during the postpartum period stimulates glucose metabolism in cows. Typical responses include decreased whole body oxidation of glucose (Cohick et al., 1989), increased hepatic rates of gluconeogenesis (Bauman et al., 1988), and decreased glucose response to insulin (Bauman and Vernon, 1993). In the current study, mean concentrations of glucose increased prepartum but only within the bST group of cows; after parturition, the expected decline was observed. Greater availability and concentrations of glucose caused by bST injections during the dry period might have resulted, either directly or indirectly, in greater concentrations of insulin in cows of the same group. Because more glucose was available from synthesis or because of reduced peripheral utilization, perhaps caused by reduced peripheral tissue response to insulin, more insulin might have been synthesized and secreted to regulate blood glucose. Conversely, a decrease in concentrations of glucose and no change in concentration of insulin during early lactation might indicate less availability of glucose in peripheral circulation because of the extremely high demands for glucose by mammary epithelial cells for synthesis of milk lactose and to provide energy to these cells. Although bST-injected cows produced significantly more milk during early lactation, they still were able to maintain nearly stable concentrations of glucose in plasma.

Typically, lower utilization of glucose and low energy intake result in greater blood plasma concentrations of NEFA and ketones during the late dry period (Petterson et al., 1993). Maternal tissues, especially during the last trimester of pregnancy, mostly rely on the metabolism of NEFA and ketone bodies (Bell, 1995). Thus, increased mobilization of NEFA during the late prepartum period is essential. Reduced DMI of ruminants before calving also is associated with greater mobiliza- tion of NEFA from adipose tissue (Forbes, 1986), especially around calving when DMI is most dramatically reduced. Importantly, in the current study, low concentrations of NEFA in plasma were detected up to the final week of pregnancy, but then a sharp increase in concentrations of NEFA in plasma was observed for all cows. Concentrations of NEFA declined after parturition, but still were more than double the prepartum concentrations, indicating greater mobilization from adipose. Greater mobilization of NEFA might have been due to increased lipolysis driven by adrenergic stimulation around parturition (Grummer, 1993) because of increasing demands for energy to support milk synthesis before DMI had increased. Furthermore, the metabolic pathways of de novo fatty acid synthesis, plasma triglyceride uptake, fatty acid esterification, and the activities of the enzymes controlling these actions are greatly reduced during late prepartum and early lactation periods (McNamara, 1991). Reduced numbers of insulin receptors, second messenger, or lower activity of insulin protease on adipocytes also may be responsible for the further increase in plasma concentrations of NEFA during this time (Marinchenko et al., 1992; McNamara et al., 1995). All these actions would favor use of NEFA by peripheral tissues rather than use of glucose. In this way, glucose is conserved for conceptus metabolism, especially during the last trimester of pregnancy, and then after calving for mammary use during the rising production of milk during early lactation.

\section{CONCLUSIONS}

Supplementation of the diets of cows with low doses of bST prepartum and postpartum allowed them to maintain and replenish their body reserves during the early postpartum period, similar to control cows, and they also produced more milk during early lactation. The DMI of bST-supplemented and control cows during the first 28 DIM also increased in a similar way. Changes in hormones and IGF-I prepartum and postpartum because of bST are reflected in increased MY and $3.5 \%$ FCM yields through $10 \mathrm{wk}$. These facts indicate that bST-supplemented cows had similar abilities to mobilize body tissues as a source of energy and to support lactation and increased DMI, which permitted greater MY. Importantly, when all cows were supplemented with a full dose of bST beginning at about 56 DIM, MY was maintained better through $21 \mathrm{wk}$ in the cows previously supplemented with bST prepartum and during early lactation. Responses observed likely involved known responses of DMI to supplemental bST, the complex interplay of hormones, growth factor, and metabolites and responses of various organs and tissues 
to provide greater quantities of important nutrients to tissues, including the lactating mammary gland. The specific mechanisms by which greater MY was stimulated by the low doses of bST were not identified, but it is likely that overall apparent efficiency of MY was improved during later lactation, as it was during early lactation. There also might have been improved maintenance of mammary cell activity and/or increased cell numbers during supplementation with low or greater doses of bST.

\section{REFERENCES}

Abribat, T. H., H. Lapierre, P. Dubreuil, G. Pelletier, P. Gaudreau, P. Brazeau, and D. Petitclerc. 1990. Insulin-like growth factor-1 concentration in Holstein female cattle: Variations with age, stage of lactation and growth hormone-releasing factor administration. Domest. Anim. Endocrinol. 7:93-102.

Bachman, K. C., D. H. Wilfond, H. H. Head, C. J. Wilcox, and M. Singh. 1992. Milk yields and hormone concentrations of Holstein cows in response to Sometribove (Somatotropin) treatment during the dry period. J. Dairy Sci. 75:1883-1890.

Bauman, D. E. 1992. Bovine somatotropin: Review of an emerging animal technology. J. Dairy Sci. 75:3432-3451.

Bauman, D. E. 1999. Bovine somatotropin and lactation: From basic science to commercial application. Domest. Anim. Endocrinol.17:101-116.

Bauman, D. E., C. J. Peel, W. D. Steinhour, P. J. Reynolds, H. F. Tyrell, A. C. G. Brown, and G. L. Haaland. 1988. Effect of bovine somatotropin on metabolism of lactating dairy cows: Influence on rates of irreversible loss and oxidation of glucose and nonesterified fatty acids. J. Nutr. 118:1031-1040.

Bauman, D. E., and R. G. Vernon. 1993. Effects of bovine somatotropin on lactation. Ann. Rev. Nutr. 13:437-461.

Baumrucker, C. C., and B. H. Stemberger. 1989. Insulin and insulinlike growth factor-I stimulate DNA synthesis in bovine mammary tissue in vitro. J. Anim. Sci. 67:3503-3514.

Bell, A.W. 1995. Regulation of organic nutrient metabolism during transition from late pregnancy to early lactation. J. Anim. Sci. 73:2804-2819.

Bines, J. A., and I. C. Hart. 1982. Metabolic limits to milk production, especially roles of growth hormone and insulin. J. Dairy Sci. 65:1375-1389.

Burvenich, C., M. J. Paape, D. Hoeben, H. Dosogne, A. M. MassartLeen, and J. Blum. 1999. Modulation of the inflammatory reaction and neutrophil defense of the bovine lactating mammary gland by growth hormone. Domest. Anim. Endocrinol. 17:149-159.

Chalupa, W., and D. T. Galligan. 1989. Nutritional implications of somatotropin for lactating cows. J. Dairy Sci. 72:2510-2524.

Cohick, W. S., K. Plaut, S. J. Sechen, and D. E. Bauman. 1989. Temporal pattern of IGF-I response to exogenous GH in lactating cows. Domest. Anim. Endocrinol. 6:263-273.

de Boer, G., P. H. Robinson, and J. J. Kennelly. 1991. Hormonal responses to bovine somatotropin and dietary protein in early lactation dairy cows. J. Dairy Sci. 74:2623-2632.

Elsasser, T. H., T. S. Rumsey, and A. C. Hammond. 1989. Influence of diet on basal and GH stimulated plasma concentrations of IGFI in beef cattle. J. Anim. Sci. 67:128-141.

Eppard, P. J., J. J. Veenhuizen, W. J. Cole, P. G. Comens-Keller, G. F. Hartnell, R.L. Hintz, L. Munyakazi, P. K. Olsson, R. H. Sorbet, T. C. White, C. A. Baile, R. J. Collier, J. P. Goff, and R. L. Horst.1996. Effect of bovine somatotropin administered to periparturient dairy cows on the incidence of metabolic disease. J. Dairy Sci. 79:2170-2181.

Ferguson, J. D., D. T. Galligan, and N. Thomsen. 1994. Principal descriptors of body condition score in Holstein cows. J. Dairy Sci. 77:2695-2703.
Forbes, J. M. 1986. The effects of sex hormones, pregnancy and lactation on digestion, metabolism, and voluntary food intake. Page 420 in Control of Digestion and Metabolism in Ruminants. L. P. Michigan, W. L. Grovum, and A. Dobson, ed. Prentice-Hall, Englewood Cliffs, NJ.

Gallo, G. F., and E. Block. 1990. Effects of recombinant bovine somatotropin on nutritional status and liver function of lactating dairy cows. J. Dairy Sci. 73:3276-3286.

Garcia, A. G. 1998. Use of bST in management of growing heifers and transition cows to improve growth rates and milk production. Ph.D. dissertation. University of Florida, Gainesville.

Grummer, R. R. 1993. Etiology of lipid-related metabolic disorders in periparturient dairy cows. J. Dairy Sci. 76:3882-3896.

Gulay, M. S. 1998. Physiological responses of Holstein cows to various bST treatments during the transition period. M.S. thesis. University of Florida, Gainesville.

Gulay, M. S. 2002. Strategies for management of transition cows using bovine somatotropin (bST), short dry period and diets to improve their performance during lactation. Ph.D. dissertation. University of Florida, Gainesville.

Gulay, M. S., A. G. Garcia, M. J. Hayen, C. J. Wilcox, and H. H. Head. 2000. Physiological responses of Holstein cows to various bST treatments during the transition period. J. Dairy Sci. (Suppl.1) 83:219.

Gulay, M. S., M. J. Hayen, K. C. Bachman, T. Belloso, M. Liboni, and H. H. Head. 2003a. Milk production and feed intake of Holstein cows given short (30-d) or normal (60-d) dry periods. J. Dairy Sci. 86:2030-2038.

Gulay, M. S., M. J. Hayen, and H. H. Head. 2001. Responses of Holstein cows to low dose of somatotropin (bST) prepartum and postpartum. J. Dairy Sci. (Suppl.1) 84:388.

Gulay, M. S., M. J. Hayen, L. C. Teixeira, C. J. Wilcox, and H. H. Head. 2003b. Responses of Holstein cows to a low dose of Somatotropin (bST) prepartum and postpartum. J. Dairy Sci. 86: 3195-3205.

Hoeben, D., C. Burvenich, and P. J. Eppard.1999. Effect of recombinant bovine somatotropin on milk production and composition of cows with Streptococcus uberis mastitis. J. Dairy Sci. 82:16711683.

Johnson, M. M., and J. P. Peters. 1993. Technical note: An improved method to quantify nonesterified fatty acids in bovine plasma. J. Anim. Sci. 71: 753-756.

Littell, R. C., G. A. Milliken, W. W. Stroup, and R. D. Wolfinger. 2000. SAS System for Mixed Models. SAS Inst., Inc., Cary, NC.

Lucy, M. C., R. L. de la Sota, C. R. Staples, and W. W. Thatcher. 1993. Ovarian follicular populations in lactating dairy cows treated with bovine somatotropin (sometribove) or saline and fed diets differing in fat content and energy. J. Dairy Sci. 76:1014-1027.

Lucy, M. C., H. Jiang, and Y. Kobayashi. 2001. Changes in the somatotropic axis associated with the initiation of lactation. J. Dairy Sci. 84(E. Suppl.):E113-E119.

Malven, P. V., H. H. Head, R. J. Collier, and F. C. Buonomo. 1987. Periparturient changes in secretion and mammary uptake of insulin and in concentrations of insulin and insulin like growth factors in milk of dairy cows. J. Dairy Sci. 70:2254-2265.

Marinchenko, G. V., J. P. McNamara, D. Sun, and B. Becker-Khaleel. 1992. Growth hormone alters metabolic effects and proteolysis of insulin in adipose tissue during lactation. Proc. Soc. Exp. Biol. Med. 200:57-66.

McGuire, M. A., J. L. Vicini, D. E. Bauman, and J. J. Veenhuizen. 1992. Insulin like growth factors and binding proteins and their nutritional regulation. J. Anim. Sci. 70:2901-2910.

McNamara, J. P. 1991. Regulation of adipose tissue metabolism in support of lactation. J. Dairy Sci. 74:706-719.

McNamara, J. P., J. H. Harrison, R. L. Kincaid, and S. S. Waltner. 1995. Lipid metabolism in adipose tissue of cows fed high fat diets during lactation. J. Dairy Sci. 78:2782-2796.

Miles, P. H., N. S. Wilkinson, and L. R. McDowell. 2001. Analysis of Minerals for Animal Nutrition Research. 3rd ed. Animal Sciences, University of Florida, Gainesville.

Moallem, U., M. Kaim, Y. Folman, and D. Sklan. 1997. Effect of calcium soaps of fatty acids and administration of somatotropin 
in early lactation on productive and reproductive performance of high producing dairy cows. J. Dairy Sci. 80:2127-2136.

Moallem, U., M. Kaim, Y. Folman, and D. Sklan. 2000. Effects of somatotropin and dietary calcium soaps of fatty acids in early lactation on milk production, dry matter intake, and energy balance of high yielding dairy cows. J. Dairy Sci. 83:2085-2094.

National Research Council. 1989. Nutrient Requirements of Dairy Cattle. 6th rev. ed. Natl. Acad. Press, Washington, DC.

Petterson, J. A., F. R. Dunshea, R. A. Ehrhardt, and A. W. Bell. 1993. Pregnancy and undernutrition alter glucose metabolic response to insulin in sheep. J. Nutr. 123:1286-1295.

Phillips, L. S., J. B. Harp, S. Godstein, J. Klein, and C. I. Pao. 1990. Regulation and action of insulin-like growth factor at the cellular level. Proc. Nutr. Soc. 49:451.

Putnam, D. E., G. A. Varga, and H. M. Dann. 1999. Metabolic and production responses to dietary protein and exogenous somatotropin in late gestation dairy cows. J. Dairy Sci. 82:982-995.

Raabo, E., and T. C. Terkildsen. 1960. The enzymatic determination of blood glucose. Scand. J. Clin. Lab. Invest. 12:402-408.

Rechler, M. M., and S. P. Nissley. 1990. Insulin-like growth factors. Handbook Exp. Pharmacol. 95:263-281.

Remond, B., M. Cisse, A. Ollier, and Y. Chilliard. 1991. Slow release somatotropin in dairy heifers and cows fed two levels of energy concentrate. 1. Performance and body condition. J. Dairy Sci. 74:1370-1381.

Richard, A. L., S. N. McCutcheon, and D. E. Bauman. 1985. Responses of dairy cows to exogenous growth hormone administered during early lactation. J. Dairy Sci. 68:2385-2389.
Ronge, H., J. Blum, C. Clement, F. Hans, and H. Binder. 1988. Somatomedin $\mathrm{C}$ in dairy cows related to energy and protein supply and to milk production. Anim. Prod. 47:165-183.

SAS User's Guide: Statistics. Vol. 5. 1991. SAS Inst., Inc., Cary, NC. Schneider, P. L., D. Sklan, D. S. Kronfeld, and W. Chalupa. 1989. Responses of dairy cows in early lactation to bovine somatotropin and ruminally inert fat. J. Dairy Sci. 73:1263-1268.

Simmons, C. R., W. G. Bergen, M. J. VandeHaar, D. J. Sprecher, C. J. Sniffen, E. P. Stanisiewski, and H. A. Tucker. 1994. Protein and fat metabolism in cows given somavubove before parturition. J. Dairy Sci. 77:1835-1847.

Stanisiewski, E. P., L. F. Krabill, and J. W. Lauderdale. 1992. Milk yield, health, and reproduction of dairy cows given somatotropin (somavubove) beginning early postpartum. J. Dairy Sci. 75:2149-2164.

Vandeputte-Van Messom, G., and C. Burvenich. 1993. Effect of somatotropin on changes in milk production and composition during coliform mastitis in periparturient cows. J. Dairy Sci 76:37273741

Vicini, J. L., F. C. Buonomo, J. J. Veenhuizen, M. A. Miller, D. R. Clemmons, and R. J. Collier. 1991. Nutrient balance and stage of lactation affect responses of insulin, insulin-like growth factors I and II, and insulin-like growth factor-binding protein 2 to somatotropin administration in dairy cows. J. Nutr. 121:1656-1664.

White, T. C., K. S. Madsen, R. L. Hintz, R. H. Sorbet, R. J. Collier, D. L. Hard, G. F. Hartnell, W. A. Samuels, G. de Kerchove, and F. Adriaens. 1994. Clinical mastitis in cows treated with sometribove (recombinant bovine somatotropin) and its relationship to milk yield. J. Dairy Sci. 77:2249-2260. 